\title{
Dampak ACFTA (ASEAN-China Free Trade Area) Terhadap Trade Creation Dan Trade Diversion Indonesia Di Kawasan ACFTA+3
}

\author{
Siti Khamila Dewi*, Sahara, Sri Mulatsih \\ Departemen Ilmu Ekonomi, Fakultas Ekonomi dan Manajemen, Institut Pertanian Bogor \\ Jalan Agatis, Kampus Darmaga, Bogor 16680, Indonesia \\ *Korespondensi: khamiladewi.kati@gmail.com
}

[diterima: Agustus 2018- revisi: September 2018-diterbitkan daring: Juli 2019]

\begin{abstract}
ABSTRAK
Indonesia terlibat aktif dalam jejaring kerjasama Free Trade Area (FTA), salah satunya dengan menjadi anggota pada ASEAN-China FTA atau dikenal juga dengan ACFTA. Studi ini bertujuan untuk menganalisis faktor yang memengaruhi nilai impor Indonesia dan mengetahui dampak ACFTA terhadap trade creation dan trade diversion Indonesia. Penelitian menggunakan pendekatan model panel data dengan data sekunder selama periode tahun 2000 hingga 2018 yang dikumpulkan dari WITS, WORLD BANK, UNCTAD, dan CEPII. Hasil empiris menunjukkan bahwa setelah ACFTA diberlakukan, nilai impor Indonesia dari negara-negara anggota ACFTA mengalami kenaikan. Nilai impor Indonesia secara signifikan dipengaruhi secara positif oleh GDP per kapita Indonesia, GDP per kapita mitra dagang (negara ACFTA+3), dan jarak ekonomi antar negara. Sementara nilai tukar riil antar negara berpengaruh negatif terhadap nilai impor Indonesia. Secara keseluruhan Indonesia diduga mengalami kerugian dari adanya ACFTA akibat terjadinya trade diversion dari negara non-anggota ke negara-negara anggota di wilayah ACFTA +3.
\end{abstract}

Kata Kunci : ACFTA+3, Impor, Panel Data, Trade Creation, Trade Diversion

\begin{abstract}
Indonesia actively involves in Free Trade Area (FTA), such as FTA between ASEAN and China or also known as ACFTA. The study aims to analyze the factors influencing the value of Indonesia's imports and determine the impact of ACFTA on Indonesia's possible trade creation and trade diversion. The study employs the panel data model on secondary data, collected from 2000 to 2018, from WITS, WORLD $B A N K$, UNCTAD, and CEPII. The empirical results show that after the ACFTA enacted, the value of Indonesia's imports from ACFTA member countries increased. The value of Indonesia's imports was significantly and positively influenced by Indonesia's GDP per capita, GDP per capita of trading partners (ACFTA +3 countries), and economic distance. Meanwhile, the real exchange rate between countries negatively affected the value of Indonesia's imports. Overall, Indonesia is expected to suffer losses from the ACFTA due to the occurrence of trade diversion from non-member countries to member countries in the ACFTA +3 region.
\end{abstract}

Keywords: ACFTA+3, Import, Panel Data, Trade Creation, Trade Diversion JEL Classifiation: F13, C33, F14, C87 


\section{PENDAHULUAN}

Liberalisasi perdagangan terus berkembang dengan munculnya perjanjian perdagangan baik di tingkat bilateral, regional, maupun multilateral. Tujuan liberalisasi perdagangan adalah untuk meningkatkan volume dan nilai perdagangan suatu negara sehingga dapat meningkatkan pertumbuhan ekonomi dan kesejahteraan masyarakat suatu negara. Menurut Baier dan Bergstrand (2001), perdagangan dunia dipengaruhi oleh tiga faktor, yaitu pertumbuhan pendapatan, penurunan hambatan perdagangan, dan penurunan biaya transportasi melalui perjanjian perdagangan bebas.

Liberalisasi perdagangan dunia mendorong tingkat integrasi dan pertumbuhan ekonomi negara-negara di dunia. Integrasi ekonomi akan membuka akses perdagangan seluas mungkin antara satu negara dengan negara lainnya. Integrasi ekonomi bertujuan untuk membuka akses perdagangan seluas mungkin antara satu negara dan lainnya. Kompetisi antar para pelaku pasar akan menyebabkan penurunan harga untuk barang dan jasa yang sejenis, dengan demikian dapat meningkatkan kualitas dan memperbanyak pilihan bagi konsumen pada wilayah yang terintegrasi. Kecenderungan peningkatan proses integrasi ekonomi dan keuangan regional di berbagai belahan dunia pada dasarnya dilandasi oleh konsep dasar bahwa manfaat yang diperoleh akan lebih besar dibandingkan risiko yang akan dihadapi (Oktaviani et al. 2014).

Keuntungan liberalisasi perdagangan antara lain untuk meningkatkan efisiensi. Peningkatan efisiensi tersebut dilakukan melalui beberapa jalur. Pertama, melalui peningkatan produktivitas karena makin efisiennya alokasi sumber daya baik dalam suatu industri maupun antar industri. Kedua, melalui peningkatan persaingan. Liberalisasi berpotensi untuk meningkatkan kompetisi antara produsen domestik dengan luar negeri, sehingga produsen domestik yang tidak efisien akan keluar dari industri selanjutnya industri secara keseluruhan akan menjadi lebih efisien. Namun, keuntungan tersebut dapat menjadi ancaman bagi perekonomian nasional. Hal tersebut tergantung pada kesiapan industri domestik serta daya saing produk-produk domestic (Astiyah et al ,2005).

Kawasan perdagangan bebas atau Free Trade Area (FTA) merupakan salah satu bentuk integrasi ekonomi di dunia dengan memberikan perlakukan khusus kepada negara mitra dagang yang masuk dalam FTA. Teori integrasi ekonomi mengacu pada suatu kebijakan komersial atau kebijakan perdagangan yang secara diskriminatif menurunkan atau menghapuskan hambatanhambatan perdagangan hanya di antara negaranegara yang saling sepakat untuk membentuk suatu integrasi ekonomi terbatas (Salvatore 1996).

Dalam kesepakatannya, FTA memberlakukan penurunan atau penghapusan hambatan perdagangan di antara anggota, yaitu dapat berupa penetapan kesepakatan tarif dan non tarif di antara anggota. Hal ini berdampak pada peningkatan alokasi sumber daya didalam kawasan dan pendapatan untuk negara-negara anggota. Perdagangan bebas akan memaksimalkan output dunia dan keuntungan bagi setiap negara yang terlibat didalamnya (Salvatore 1997). Free Trade Area (FTA) diatur pada pasal XXIV GATT 1994/ WTO memberikan rambu-rambu pembentukan wilayah pabean bersama atau pabean tunggal (customs union) dan FTA. FTA memberikan kontribusi penting terhadap kemajuan liberalisasi perdagangan bilateral, regional, dan multilateral.

Seiring dengan pertumbuhan ekonomi di dalam perdagangan internasional, ASEAN sebagai salah satu kawasan integrasi ekonomi membuat komitmen untuk melakukan integrasi ekonomi dan liberalisasi perdagangan dengan membentuk ASEAN Free Trade Area (AFTA) pada tahun 1992. Tujuan dari AFTA adalah untuk meningkatkan daya saing ASEAN sebagai basis produksi untuk pasar dunia melalui liberalisasi perdagangan dan kerja sama ekonomi yang lebih dekat (Thangavelu, Chongvilaivan 2009). Salah satu peningkatan integrasi ekonomi ASEAN yaitu ASEAN-China Free Trade Area (ACFTA). Kerangka perjanjian ACFTA yaitu negara-negara yang menjadi anggota perjanjian saling memberikan preferential treatment di tiga sektor: sektor barang, jasa dan investasi dengan tujuan 
memacu percepatan aliran barang, jasa dan investasi diantara negara-negara anggota sehingga dapat terbentuk suatu kawasan perdagangan bebas. Preferential treatment adalah perlakuan khusus yang lebih menguntungkan dibandingkan perlakuan yang diberikan kepada negara mitra dagang lain non anggota pada umumnya. Kesepakatan di sektor barang, komponen utamanya adalah preferential tariff.

Proses menuju kesepakatan perjanjian ACFTA diawali dengan dilakukannya pertemuan tingkat kepala negara antara negara-negara ASEAN dan Cina di Bandar Seri Begawan, Brunei pada tanggal 6 Nopember 2001 yang kemudian disahkan melalui penandatanganan "Persetujuan Kerangka Kerja mengenai Kerjasama Ekonomi Menyeluruh antara Negara-negara Anggota ASEAN dan Republik Rakyat Cina" di Phnom Penh, Kamboja pada tanggal 4 Nopember 2002. ASEAN dan Cina menyetujui dibentuknya ACFTA dalam dua tahapan yaitu tahun 2010 dengan negara pendiri ASEAN dan pada tahun 2012 dengan negara anggota baru ASEAN. Indonesia telah meratifikasi Framework Agreement ASEAN-China FTA melalui Keputusan Presiden Nomor 48 Tahun 2004 tanggal 15 Juni 2004. Setelah negosiasi tuntas, secara formal ACFTA pertama kali diluncurkan sejak ditandatanganinya Trade in Goods Agreement dan Dispute Settlement Mechanism Agreement pada tanggal 29 November 2004 di Vientiane, Laos.

Peningkatan transaksi perdagangan antara ASEAN dengan negara mitra dagang menunjukan tingkat kerjasama dan tingkat keterbukaan antar negara tersebut semakin tinggi. Nilai total perdagangan ASEAN pada tahun 2018 yaitu sebesar 1.4 Triliun USD (Trademap 2019). Gambar 1 menunjukan persentase total perdagangan barang ASEAN dengan mitra dagangnya pada tahun 2018. Persentase terbesar total perdagangan ASEAN yaitu dengan Cina yang memiliki nilai total perdagangan sebesar 223 Miliar USD atau sebesar 19 persen dari total perdagangan ASEAN ke seluruh mitra dagangnya. Nilai total perdagangan ASEAN-Cina memiliki rata-rata pertumbuhan 11 persen dalam lima tahun terakhir. Hal ini menandakan bahwa tingkat kerjasama dan keterbukaan perdagangan diantara keduanya yang cukup kuat dibandingkan negaranegara mitra dagang lainnya. Sementara mitra dagang utama ASEAN di luar kawasan yaitu negara Amerika, Jepang, Korea dan India.

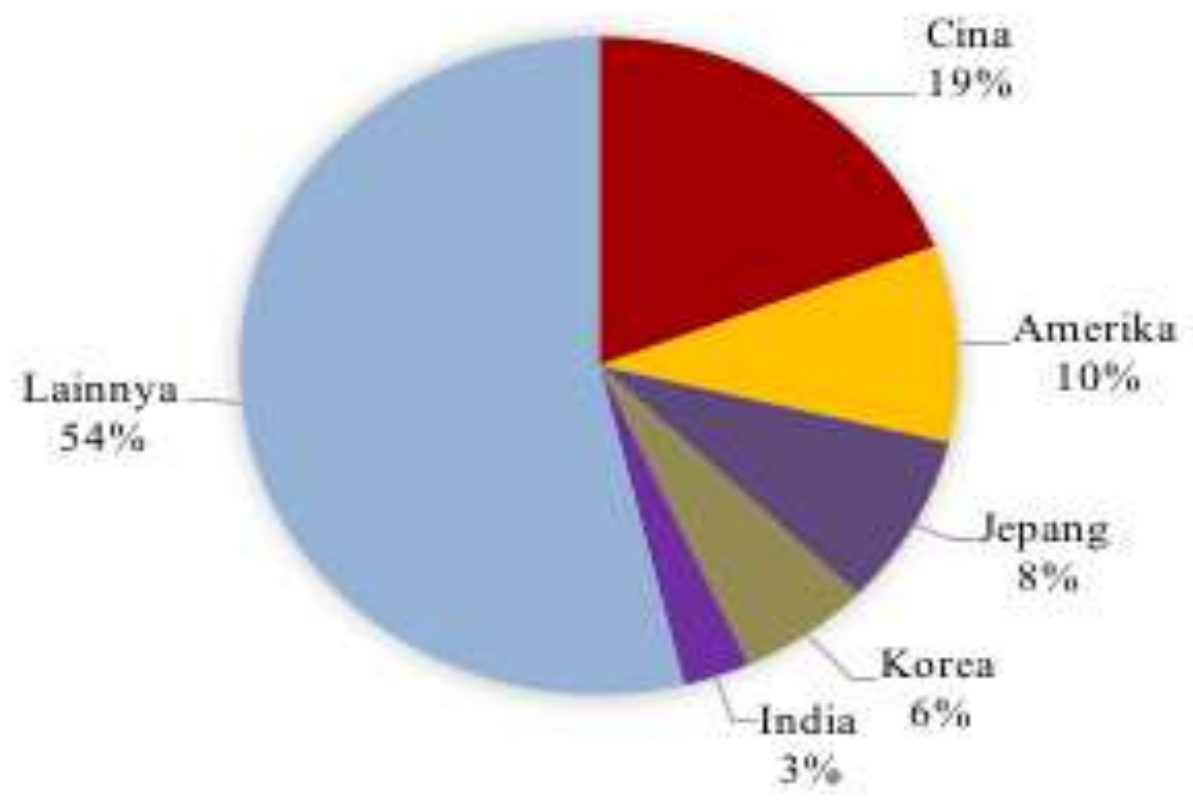

Sumber : Trademap 2019 (diolah)

Gambar 1. Presentase total perdagangan ASEAN dengan negara mitra dagang tahun 2018 (\%) 
Indonesia sebagai salah satu negara berkembang ASEAN yang aktif dalam kerjasama perdagangan dengan Cina dan menunjukan peningkatan pada transaksi perdagangan setelah ACFTA. Gambar 2 menunjukan persentase total perdagangan ekspor dan impor Indonesia pada tahun 2018. Cina memiliki nilai persentase total perdagangan tertinggi dibanding negara mitra dagang utama lainnya yaitu 20 persen dari nilai total impor Indonesia. Nilai total perdagangan
Indonesia-Cina hampir mencapai 73 Miliar USD pada tahun 2018 (Trademap 2019). Hal ini memnjukan bahwa Indonesia-Cina memiliki kerjasama perdagangan yang paling kuat diantara negara mitra dagang lainnya. Dilihat dari persentase total nilai perdagangannya, mitra dagang utama lain Indonesia diantaranya yaitu Jepang (10 persen), Singapura (9 persen), Amerika (8 persen), dan Korea (5 persen).

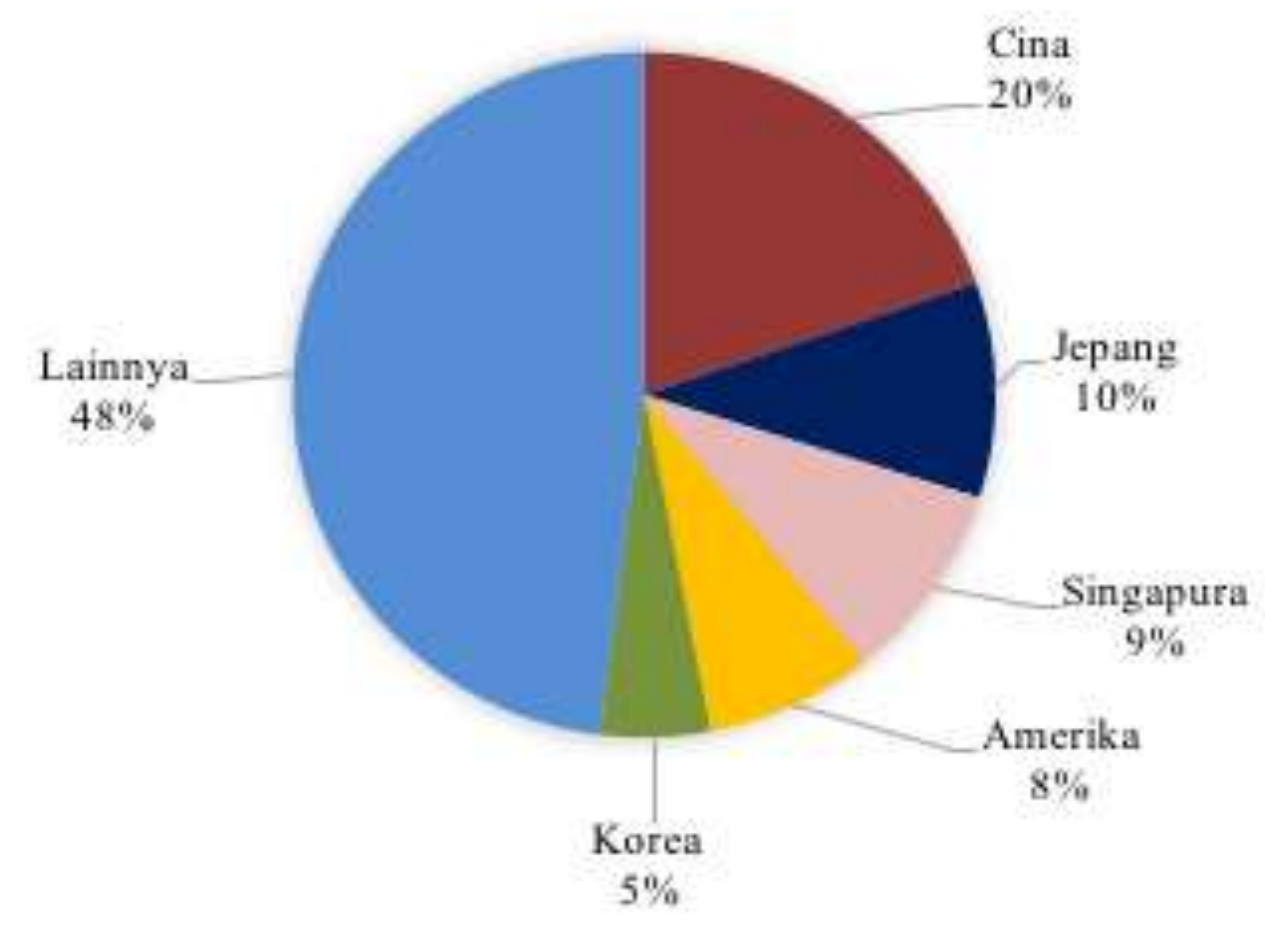

2019 (diolah)

Sumber : Trademap

Gambar 2. Presentase total perdagangan Indonesia dengan negara mitra dagang tahun $2018(\%)$

Perjanjian perdagangan sebagai bentuk liberalisasi ekonomi memiliki dampak positif maupun negatif terhadap setiap anggotanya. Dampak positif yang dapat terjadi antara lain meningkatkan investasi, meningkatkan devisa, memperluas lapangan kerja, meningkatkan daya saing, meningkatkan kemampuan sumber daya manusia, memperluas diversifikasi produk, dan memperbaiki neraca perdagangan. Sedangkan dampak produk asing, terpengaruhnya perekonomian nasional oleh situasi dunia, terpengaruhnya kebijakan pembangunan nasional, terbentuknya proteksi non tarif, dan eksploitasi sumber daya (Oktaviani et al. 2014).
Khor (2002) berpendapat bahwa globalisasi ekonomi memengaruhi berbagai kelompok negara secara berbeda. Secara umum, dampak dari proses ini dapat dikelompokkan ke dalam tiga kelompok negara. Kelompok pertama adalah sejumlah kecil negara yang mempelopori atau terlibat secara penuh dalam proses globalisasi ekonomi serta mengalami pertumbuhan dan perluasan kegiatan ekonomi secara pesat, yaitu negara-negara maju. Kelompok kedua adalah negara-negara yang mengalami pertumbuhan ekonomi yang sedang dan fluktuatif, yaitu negara-negara yang berusaha menyesuaikan diri dengan kerangka globalisasi ekonomi atau liberalisasi perdagangan dan investasi seperti negara-negara industri baru. 
Kelompok ketiga adalah negara-negara yang termarjinalisasikan atau yang sangat dirugikan karena ketidakmampuan mengatasi tantangantantangan yang muncul dari proses globalisasi ekonomi, kelompok ini didominasi oleh negara berkembang.

Teori integrasi ekonomi menurut kaum liberal menyatakan bahwa perdagangan bebas akan membawa perdamaian dalam hubungan internasional. Hal ini karena perdagangan bebas akan menciptakan interdependensi dan kerjasama saling menguntungkan antar negara-negara pelaku pasar. Kaum liberal berpendapat bahwa liberalisasi dalam ekonomi akan mengarah kepada kebebasan pasar dan minimalisasi peran Negara. Di sisi lain, ancaman yang datang dari terbentuknya integrasi ekonomi yaitu dapat membatasi kewenangan suatu negara untuk menggunakan kebijakannya dalam memengaruhi kinerja ekonomi dalam negeri. Selain itu, negara yang tidak mampu bersaing hanya dijadikan pasar bagi negara-negara lain yang berdaya saing tinggi yang pada akhirnya dapat memperburuk perekonomian negara tersebut.

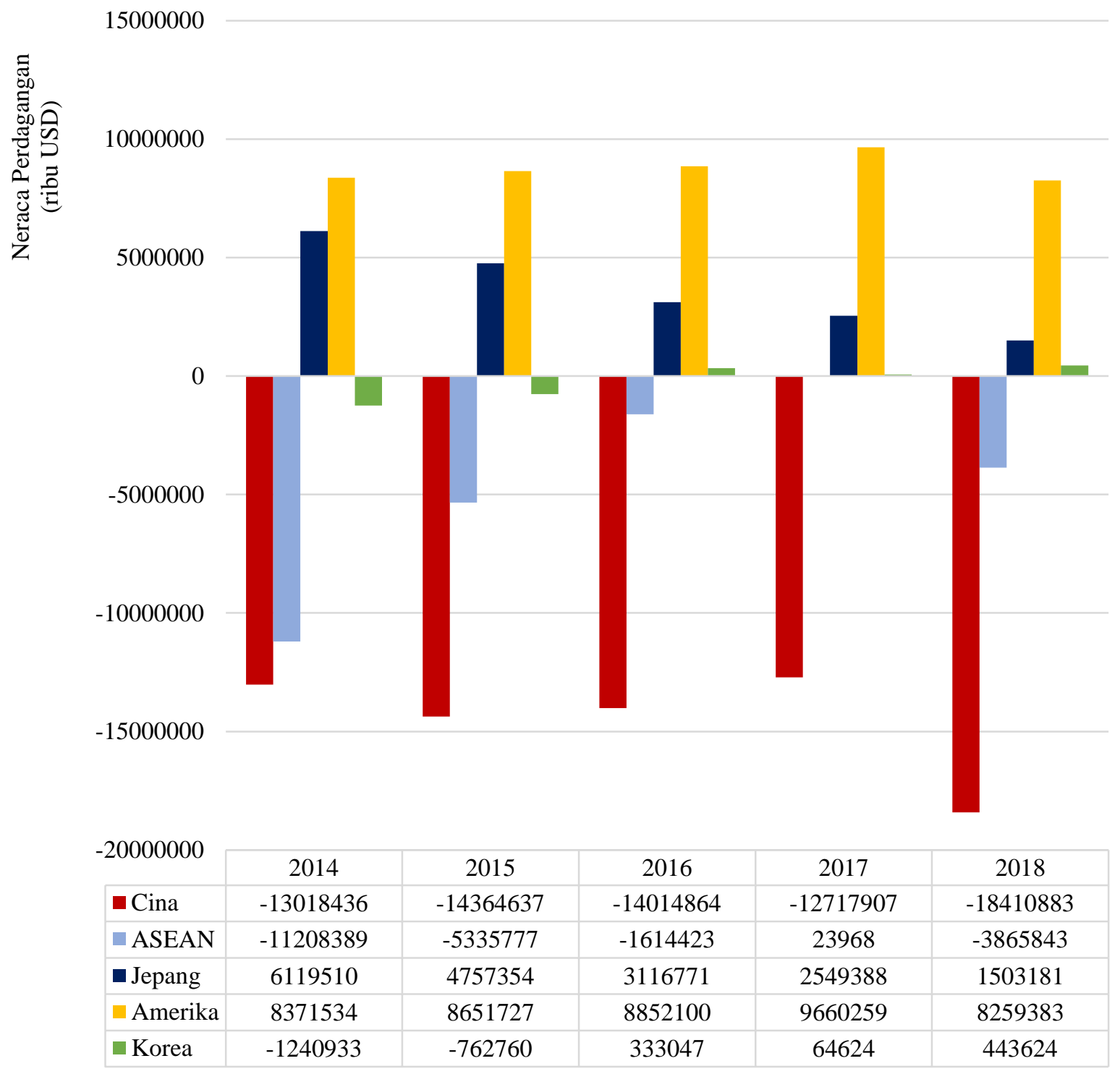

Sumber : Trademap 2019

Gambar 3. Perkembangan neraca perdagangan Indonesia dengan negara-negara ACFTA+3 Tahun 20142018 (juta USD) 
Gambar 3 menunjukan neraca perdagangan Indonesia dengan negara-negara ACFTA+3. Terlihat bahwa neraca perdagangan Indonesia-Cina terus mengalami defisit pada beberapa tahun terakhir. Pada tahun 2018 defisit perdagangan Indonesia-Cina mencapai 18.41 Miliar USD. Neraca perdagangan Indonesia dengan negaranegara ASEAN pun masih negatif. Hal tersbebut dapat menunjukan bahwa impor Indonesia dari negara-negara ACFTA lebih tinggi daripara ekspornya. Sementara itu, neraca perdagangan Indonesia dengan negara-negara mitra dagang utama lainnya cenderung menunjukan nilai yang positif. Amerika menjadi negara penyumbang defisit terbesar dengan nilai neraca perdagangan pada tahun 2018 sebesar 8.25 Miliar USD. Meskipun neraca perdagangan Indonesia-Jepang mengalami penurunan dalam lima tahun terakhir namun nilai neraca perdagangannya masih positif dengan nilai neraca perdagangan sebsar 1.50 Miliar USD. Di lain sisi, perdagangan IndonesiaKorea mengalami peningkatan nilai neraca perdagangan yang sebelumnya pada tahun 20142015 bernilai negatif menjadi positif dan pada tahun 2018 necara perdagangannya mencapai 443.62 juta USD.

Dua isu besar yang terjadi pada ekonomi global saat ini yaitu pertama berkembangnya kekuatan ekonomi baru yang berperan penting dalam perekonomian global. Kekuatan ini dimotori oleh negara berpenduduk besar seperti Cina, India, Brazil dan beberapa negara berkembang lainnya. Kedua, adanya peningkatan produksi dan perdagangan oleh berkembangnya sistem perdagangan alternatif termasuk di dalamnya global value chain. Perkembangan global value chain (GVC) menyebabkan meningkatnya pemisahan proses produksi di seluruh dunia. Indonesia seperti banyak negara lain memiliki keinginan besar untuk memerbaiki posisinya dalam GVC. Tingkat keterbukaan ekonomi yang ditunjukkan dengan pengurangan dan penghapusan berbagai hambatan dalam kegiatan perdagangan baik hambatan tarif maupun hambatan non tarif memengaruhi tingkat partisipasi suatu negara dalam GVC (Kemendag 2015).
Partisipasi dalam global value chain mampu meningkatkan nilai tambah pada sektor industri barang dan jasa. Tentu hal ini menjadi bukti bahwa global value chain dapat memainkan peran sebagai opsi perdagangan bagi negara berkembang (Kemendag 2015). Salah satu opsi kegiatan perdagangan bagi negara berkembang yaitu dengan adanya kegiatan impor barang untuk pemenuhan rantai produksi global yang akan diolah dalam negeri kemudian diekspor untuk mendapatkan nilai tambah dan keuntungan bagi negara tersebut. Integrasi ekonomi dalam kawasan ACFTA akan mendorong pertumbuhan industri di dalam negeri dengan memanfaatkan supply chain yang semakin efisien dan Indonesia menjadi bagian dari jaringan produksi global (global supply chain).

Perkembangan opsi perdagangan dan adanya integrasi ekonomi global akan memengaruhi arus perdagangan Indonesia, terutama peningkatan impor Indonesia. Dampak adanya integrasi ekonomi dapat bersifat statis yang ditandai dengan adanya trade creation dan trade diversion, dan dampak dinamis ditunjukan dengan adanya produktivitas yang lebih tinggi dan terjadi akumulasi modal yang selanjutnya berdampak pada pertumbuhan ekonomi (Salvatore 1996). Trade creation (penciptaan perdagangan) terjadi ketika beberapa produk yang produksi dalam negeri digantikan oleh produk impor dengan biaya produksi yang relatif lebih murah yang mana produknya berasal dari negara anggota, maka dengan adanya kegiatan ini maka akan meningkatkan kesejahteraan negara-negara tersebut. Sementara trade diversion terjadi ketika barang impor dengan biaya yang lebih rendah dari luar serikat atau non anggota digantikan oleh barang impor dengan biaya yang lebih tinggi dari negara anggota, dengan sendirinya hal ini akan mengurangi kesejahteraan (Salvatore 1996).

Beberapa studi terdahulu menunjukkan bahwa adanya integrasi ekonomi kawasan memiliki dampak berbeda. Studi dari Sharma dan Chua (2000) dan Thornton dan Goglio (2002) dianggap sebagai literatur pertama yang menentukan baik terdapat perdagangan antarwilayah antara negaranegara anggota ASEAN berdasarkan Gravity 
Model. Data yang digunakan tercakup hingga pertengahan tahun 1990. Sharma dan Chua (2000) menyimpulkan bahwa AFTA tidak menyebabkan dampak kreasi perdagangan sejak kurang dari seperlima perdagangan mereka diadakan antar negara blok anggota. Kemudian penelitian Thornton dan Goglio (2002) menyatakan bahwa Asia Tenggara memiliki perdagangan antar wilayah akibat jarak yang dekat, kemudian ukuran ekonomi dan bahasa antar negara-negara anggota.

Penelitian Elliot dan Ikemoto (2004) menggunakan data pada periode setelah 1997 dengan persamaan Gravity dan periode sampel yang sama untuk mengevaluasi pola perdagangan dari AFTA. Elliot dan Ikemoto (2004) membagi periode contoh dari 1982 hingga 1990 kepada enam periode waktu yang berbeda untuk membandingkan efek yang terjadi sebelum dan sesudah pembentukan AFTA, European Economic Community (EEC) dan NAFTA. Penemuan utama yaitu mengenai derajat kreasi perdagangan antara negara-negara anggota AFTA sejak 1997 rendah sejak negara-negara anggota diharuskan untuk berkompetisi dengan negara industri baru seperti Cina, Amerika Selatan dan Eropa Timur. Setelah 1997, terdapat impor negatif yang signifikan dimana efek diversi perdagangan sebagai negaranegara anggota AFTA lebih memilih untuk impor barang dari negara-negara anggota dibandingkan dengan negara non-anggota. Pada waktu yang sama, diversi ekspor perdagangan negatif memperkuat anggota AFTA untuk lebih ekspor ke negara-negara non-anggota dibandingkan dengan negara anggota.

Roberts (2004) meneliti tentang arus perdagangan yang terjadi pada ASEAN-China FTA dengan menganalisis PDB, PDB per kapita masing-masing negara anggota, perbedaan PDB per kapita, dan biaya jarak perdagangan antar pasangan negara sebagai variabel bebas. Dengan judul penelitian A Gravity Study of the Proposed Cina-ASEAN Free Trade Area, peneliti mempunyai tujuan untuk menguji kesesuaian model gravity untuk Regional Trade Area (RTA) yang diusulkan, dan mencari tahu dari implikasi kebijakan yang ada terhadap RTA yang diusulkan dan Multilateral Trade System. Hasil yang didapat menunjukkan bahwa variabel biaya jarak perdagangan mempunyai efek yang signifikan terhadap arus perdagangan dan nilai koefisien dari perbedaan PDB per kapita yang tidak signifikan mengartikan bahwa ASEAN-China FTA tidak memiliki pola permintaan yang sama dan sektor manufaktur lebih memproduksi barang yang berbeda untuk setiap pasar. Hal ini membawa negara anggota ASEAN-China untuk memetakan kebijakan dan strateginya dalam mengkonvergensi tingkat pendapatan dengan manfaat maksimum sebagai harapan dari usulan FTA.

Di sisi lain, Zidi dan Dhifallah (2013) melakukan analisis dampak yang akan terjadi pada arus perdagangan di Tunisia-EU FTA berupa terjadinya trade creation atau trade diversion. Gravity model digunakan dalam menguji variabelvariabel yang dipakai dengan rentang waktu dari tahun 1986-2010 dengan melibatkan 41 negara. Hasil yang didapat adalah tidak terjadi trade creation antara Tunisia-EU dan terjadi trade diversion pada ekspor yang dilakukan oleh Tunisia.

Selain itu penelitian Yang dan MartinezZarzoso (2013) tentang dampak trade creation dan trade diversion pada ekspor dalam kawasan ASEAN-China FTA (ACFTA) dari tahun 1995 2010. Data yang dipakai berupa data ekspor aggregate dan disaggregated untuk bahan mentah pertanian, barang-barang manufaktur dan produk kimia, juga peralatan mesin dan transport. Hasil yang diperoleh dari analisis ini yaitu secara keseluruhan ACFTA memberikan dampak trade creation bagi negara-negara anggotanya tetapi pengurangan dan penghapusan tarif untuk produkproduk sensitif seperti produk pertanian masih belum dapat dilakukan dalam ACFTA. Untuk mendapatkan peningkatan dalam kerja sama regional, ACFTA perlu meningkatkan efisiensi produksi, persaingan produk dan penggantian struktur perdagangan.

Kemudian beberapa penelitian menunjukkan dampak berbeda dari hasil integrasi ekonomi yang dilakukan dengan mitra dagangnya. Penelitian Ritaningsih (2014) menyajikan gambaran 
mengenai dampak pemberlakuan dari perjanjian perdagangan barang Indonesia pada ASEANKorea FTA. Tujuan utama penelitiannya untuk menganalisis terjadinya trade creation dan trade diversion di sektor perdagangan antara Indonesia dan negara-negara ASEAN-Korea. Pendekatan ekonometrika digunakan untuk estimasi model gravity. Hasil empiris menunjukkan bahwa secara keseluruhan sektor perdagangan Indonesia mengalami kerugian akibat terjadinya trade diversion dan tidak terjadi trade creation. Arus perdagangan impor Indonesia dengan negaranegara nonanggota ASEAN-Korea sebesar 68 persen lebih sedikit dari tingkat perdagangan yang saat ini telah dilakukan.

Sementara itu Darsono (2015) menggunakan model gravity untuk menganalisis faktor-faktor impor Indonesia dengan negara ASEAN-Jepang serta non anggota serta adanya trade creation atau trade diversion dari dampak FTA antara ASEAN dan Jepang yang disebut ASEAN-Japan Comprehensive Economic Partnership (AJCEP) telah berlangsung sejak tahun 2002. Hasil penelitian menemukan adanya trade creation pada arus impor pada negara-negara ASEAN-Jepang dan non anggota.

Oleh karena eratnya integrasi ekonomi ACFTA dan perdagangan Indonesia dengan Cina, sementara data performa perdagangan Indonesia menunjukan hasil yang kurang memuaskan, maka diperlukan kajian dampak ACFTA terutama terhadap arus impor Indonesia. Oleh karena itu berdasarkan uraian diatas dapat ditarik permasalahan yang akan dibahas dalam penelitian ini yaitu :

a. Bagaimana Gambaran Umum Karakter Ekonomi dan Perdagangan Impor Indonesia dan negara-negara ACFTA+3?

b. Faktor-faktor apa saja yang memengaruhi impor negara Indonesia di kawasan ACFTA+3?

c. Bagaimana dampak ACFTA terhadap trade creation dan trade diversion Indonesia di kawasan ACFTA+3?

\section{HIPOTESIS}

Berdasarkan tinjauan teori dan penelitian sbelumnya maka dapat kita ambil hipotesis

1. GDP per kapita Indonesia signifikan berpengaruh positif terhadap nilai impor Indonesia.

2. GDP per kapita Indonesia berpengaruh positif terhadap nilai impor Indonesia.

3. Biaya perdagangan antar negara dagang dengan proxi pada jarak ekonomi berhubungan negatif dengan nilai impor Indonesia, artinya semakin jauh besar jarak ekonomi kedua negara akan mengurangi nilai impor Indonesia.

4. Nilai tukar antara dua negara akan berpengaruh negatif pada nilai impor Indonesia. Apresiasi nilai tukar Indonesia akan mengingkatkan nilai impor Indonesia.

5. Pemberlakuan FTA akan memengaruhi nilai impor Indonesia, dimana terdapat perbedaan sebelum dan sesudah pemberlakuan ACFTA terhadap nilai impor Indonesia.

Pemberlakuan FTA akan mencipatan dampak trade creation dan atau trade diversion pada perdagangan impor Indonesia

\section{METODE}

Jenis data yang digunakan yaitu data sekunder dalam bentuk data panel, gabungan dari data time series dan data cross section. Data yang digunakan yaitu nilai impor Indonesia dengan negara mitra dagang, GDP per kapita Indonesia dan negeara mita dagang, nilai tukar Indonesia dengan negara mitra dagang, serta jarak. Sumber data berasal dari WITS, World Bank, UNCTAD, dan CEPII. Data time series yang digunakan adalah data tahunan pada tahun 2000 hingga 2018 dan cross section yang terdiri dari anggota ACFTA+3 yaitu Indonesia, Malaysia, Filipina, Singapura, Thailand, China, Amerika, Jepang dan Korea.

Setelah dilakukan beberapa pengujian model, maka spesifikasi model yang digunakan dalam penelitian mengacu pada model yang digunakan oleh penelitian Zidi dan Dhifallah (2013), serta penelitian Ritaningsih (2014). Selanjutnya proses analisis dampak ACFTA terhadap arus 
perdagangan nilai impor di Indonesia ini digambarkan oleh model sebagai berikut:

$$
\begin{aligned}
\operatorname{lnIM}_{\mathrm{ijt}}= & \beta_{0}+\beta_{1} \operatorname{lnGDPC}_{\mathrm{it}}+\beta_{2} \operatorname{lnGDPC}_{\mathrm{jt}}+ \\
& \beta_{3} \operatorname{lnRER} \mathrm{ln}_{\mathrm{ijt}}+\beta_{4} \operatorname{lnDIST}_{\mathrm{ijt}}+\beta_{5} \mathrm{DFTA}_{\mathrm{t}}+\beta_{6} \\
& \mathrm{DIM}_{\mathrm{cr}}+\beta_{7} \mathrm{DIM}_{\mathrm{dv}}+\varepsilon_{\mathrm{it}}
\end{aligned}
$$

dimana :

i : Negara Indonesia

j : Negara ACFTA+3

t : Waktu

$\mathrm{IM}_{\mathrm{ijt}} \quad$ : Nilai impor dari negara $\mathrm{j}$ ke negara $\mathrm{i}$ tahun ke-t (ribu USD)

GDPC $_{\text {it }}$ : Pendapatan per kapita negara i tahun ke-t (USD)

$\mathrm{GDPC}_{\mathrm{jt}}$ : Pendapatan per kapita negara $\mathrm{j}$ tahun ke-t (USD)

$\operatorname{RER}_{\mathrm{ijt}} \quad$ : Nilai tukar riil negara i terhadap negara $\mathrm{j}$ pada tahun ke-t

Nilai tukar riil $=($ Nilai tukar nominal negara $\mathrm{i} /$ negara $\mathrm{j})_{\mathrm{t}} \times\left(\mathrm{CPI}_{\mathrm{j}} / \mathrm{CPI}_{\mathrm{i}}\right)_{\mathrm{t}}$

DIST $_{\mathrm{ijt}} \quad$ : Jarak ekonomi negara i ke negara $\mathrm{j}$ tahun ke t

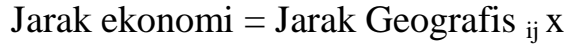
GDP $_{\mathrm{j}} / \sum_{\mathrm{i}=0} \mathrm{GDP}_{\mathrm{j}}$

DFTA $_{t}$ : Variabel dummy untuk mengindikasikan tahun pemberlakukan FTA, $(1=$ tahun ke-t setelah tahun 2004, $0=$ tahun ke-t sebelum 2004)

DIM $_{\mathrm{cr}} \quad$ : Variabel dummy untuk mengindikasikan efek dari trade creation.

$(1$ = negara pengekspor $\mathrm{j}$ adalah negara anggota ACFTA, 0 = untuk lainnya)

DIM $_{\mathrm{dv}}$ : Variabel dummy untuk mengindikasikan efek trade diversion impor.

$(1=$ negara pengekspor $\mathrm{j}$ adalah Amerika, Jepang, Korea, $0=$ untuk lainnya)

Variabel dummy yang mengindikasikan efek trade creation dan trade diversion dapat disimpulkan sebagai berikut

- Terjadi efek trade creation jika $\beta_{6}$ dan $\beta_{7}$ bertanda positif

- Terjadi efek trade diversion jika $\beta_{6}$ bertanda positif dan $\beta_{7}$ bertanda negatif

$$
\begin{aligned}
& \ln : \text { log natural } \\
& \beta_{0}: \text { intersep } \\
& \beta_{1-7}: \text { slope } \\
& \varepsilon \quad: \text { error }
\end{aligned}
$$

\section{HASIL DAN PEMBAHASAN}

\section{Gambaran Umum Karakter Ekonomi dan Perdagangan Impor Indonesia dan Negara- Negara ACFTA+3}

Setiap negara ACFTA+3 memiliki karakter perekonomian yang berbeda. Adapun pertumbuhan ekonomi merupakan salah satu indikator yang amat penting dalam melakukan analisis tentang pembangunan ekonomi suatu negara. Pertumbuhan ekonomi akan menghasilkan tambahan pendapatan masyarakat pada suatu periode tertentu, karena pada dasarnya aktivitas perekonomian adalah suatu proses penggunaan faktor-faktor produksi untuk menghasilkan output, maka proses ini pada gilirannya akan menghasilkan suatu aliran balas jasa terhadap faktor produksi yang dimiliki oleh masyarakat (Mankiw 2003).

GDP riil adalah nilai barang dan jasa yang diukur dengan menggunakan harga konstan. GDP riil menunjukkan apa yang akan terjadi terhadap pengeluaran atas output jika jumlah berubah dengan harga konstan pada waktu tertentu. Oleh karena itu GDP riil merupakan ukuran produksi barang dan jasa dalam perekonomian. GDP riil mencerminkan kemampuan perekonomian untuk memenuhi kebutuhan dan hasrat orang (Mankiw 2006).

Khor (2002) menyatakan bahwa globalisasi ekonomi memengaruhi berbagai kelompok negara juga secara berbeda. Kelompok pertama adalah sejumlah kecil negara yang mempelopori atau terlibat secara penuh dalam proses globalisasi ekonomi serta mengalami pertumbuhan dan perluasan kegiatan ekonomi secara pesat, yaitu negara-negara maju. Kelompok kedua adalah negara-negara yang mengalami pertumbuhan ekonomi yang sedang dan fluktuatif, yaitu negaranegara yang berusaha menyesuaikan diri dengan kerangka globalisasi ekonomi atau liberalisasi perdagangan dan investasi seperti negara-negara 
industri baru. Kelompok ketiga adalah negaranegara yang termarjinalisasikan atau yang sangat dirugikan karena ketidakmampuan mengatasi tantangan-tantangan yang muncul dari proses globalisasi ekonomi, kelompok ini didominasi oleh negara berkembang.

Pada Gambar 4 dapat dilihat perkembangan nilai GDP riil atau pendapatan riil negara-negara ACFTA+3 sebagai pengaruh globalisasi yang digolongkan menjadi ketiga kelompok. Negara Cina dan Amerika dapat dikatakan sebagai negaranegara kelompok pertama, dimana memiliki pertumbuhan ekonomi yang pesat. Cina memiliki rata-rata pertumbuhan GDP rill dari tahun 2000 hingga 2018 mencapai 9.1 persen, dimana pertumbuhan tertingganya mencapai 14.2 persen pada tahun 2007, dan GDP rill pada tahun 2018 mencapai 10.8 Triliun USD. Kemudian Amerika memiliki sebagai negara maju masih menduduki nilai GDP riil tertinggi pada tahun 2018 mencapai 17.8 Triliun USD. Rata-rata pertumbuhan dari tahun 2000 hingga 2018 yaitu 1.9 persen meskipun sempat mengalami krisis pada tahun 2008-2009 yang berakibat penurunan GDP riil di tahun 2010 hingga 20.5 Miliar USD, namun negara Amerika mampu bangkit dan menstabilkan pendapatan riil mereka dengan pertumbuhan ekonomi rata-rata 2.4 persen di tahun-tahun berikutnya (Trademap, 2019).

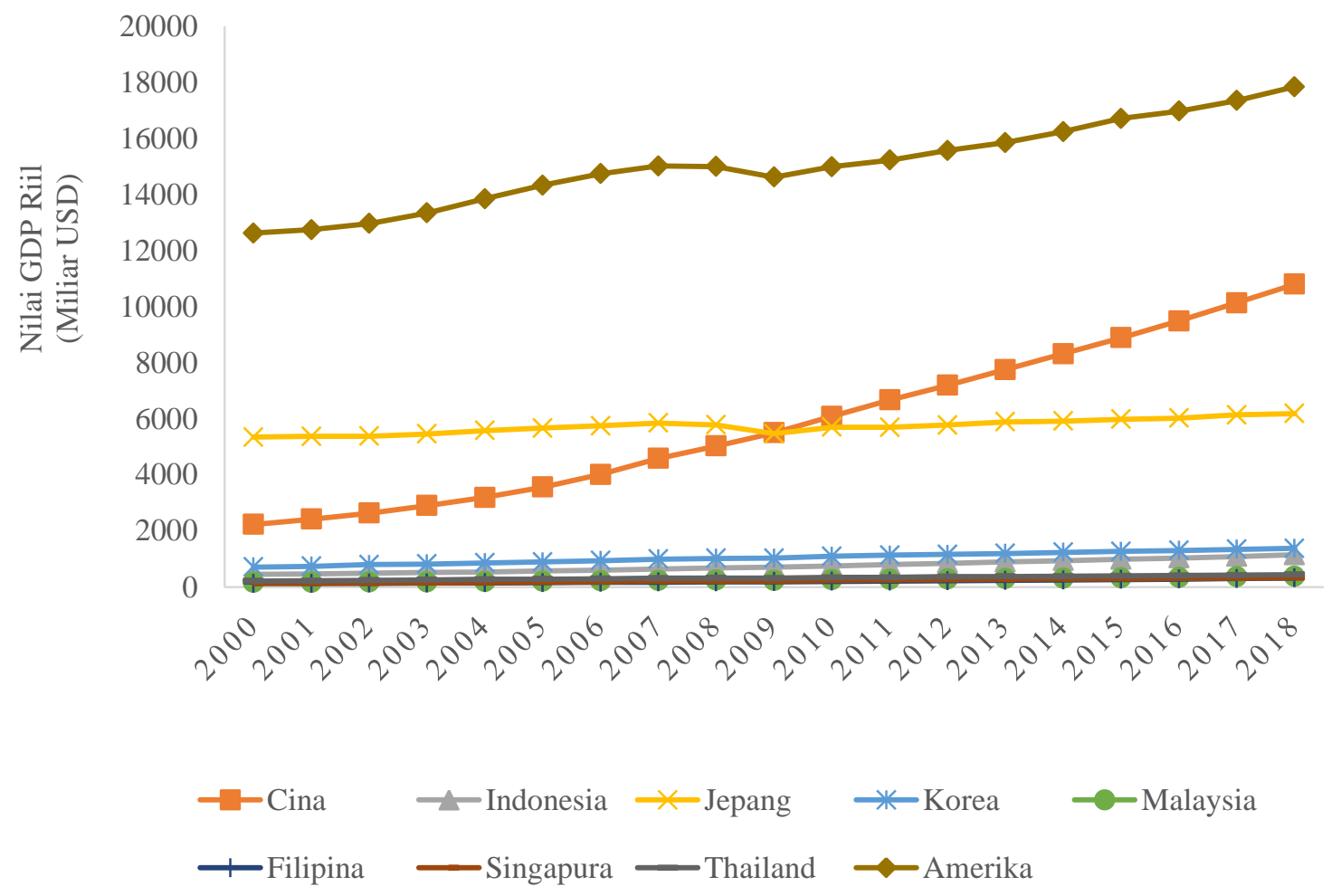

Sumber : World Bank 2019

Gambar 4. Nilai GDP riil negara ACFTA+3 tahun 2000-2018 dengan harga konstan tahun 2010 (Miliar USD)

Negara Singapura memiliki rata-rata memiliki nilai GDP riil yang tinggi dengan pertumbuhan GDP riil dari tahun 2000-2018 mengembangkan industri jasa dan pusat sebesar 5.1 persen. Dibandingkan dengan luasan perdagangan di Asia Tenggara. Negara-negara negaranya, Singapura menjadi negara yang lainnya seperti Indonesia, Thailand, Malaysia dan 
Filipina dapat menjadi negara kelompok ketiga. Thailand, Malaysia dan Filipina memiliki rata-rata GDP riil sebesar 327.7 Miliar USD, 254.9 Miliar USD, dan 201.8 Miliar USD. Indonesia sendiri memiliki rata-rata pertumbuhan GDP riil sebesar 5.3 persen dari tahun 2000-2018 dan pada tahun 2018 memiliki nilai GDP riil mencapai 1146.8
Miliar USD (World Bank 2019). Sebagai negara berkembang Indonesia dapat masuk dalam kelompok ketiga yang akan dirugikan apabila tidak memilili kemampuan mengatasi tantangantantangan yang muncul dari proses globalisasi ekonomi.

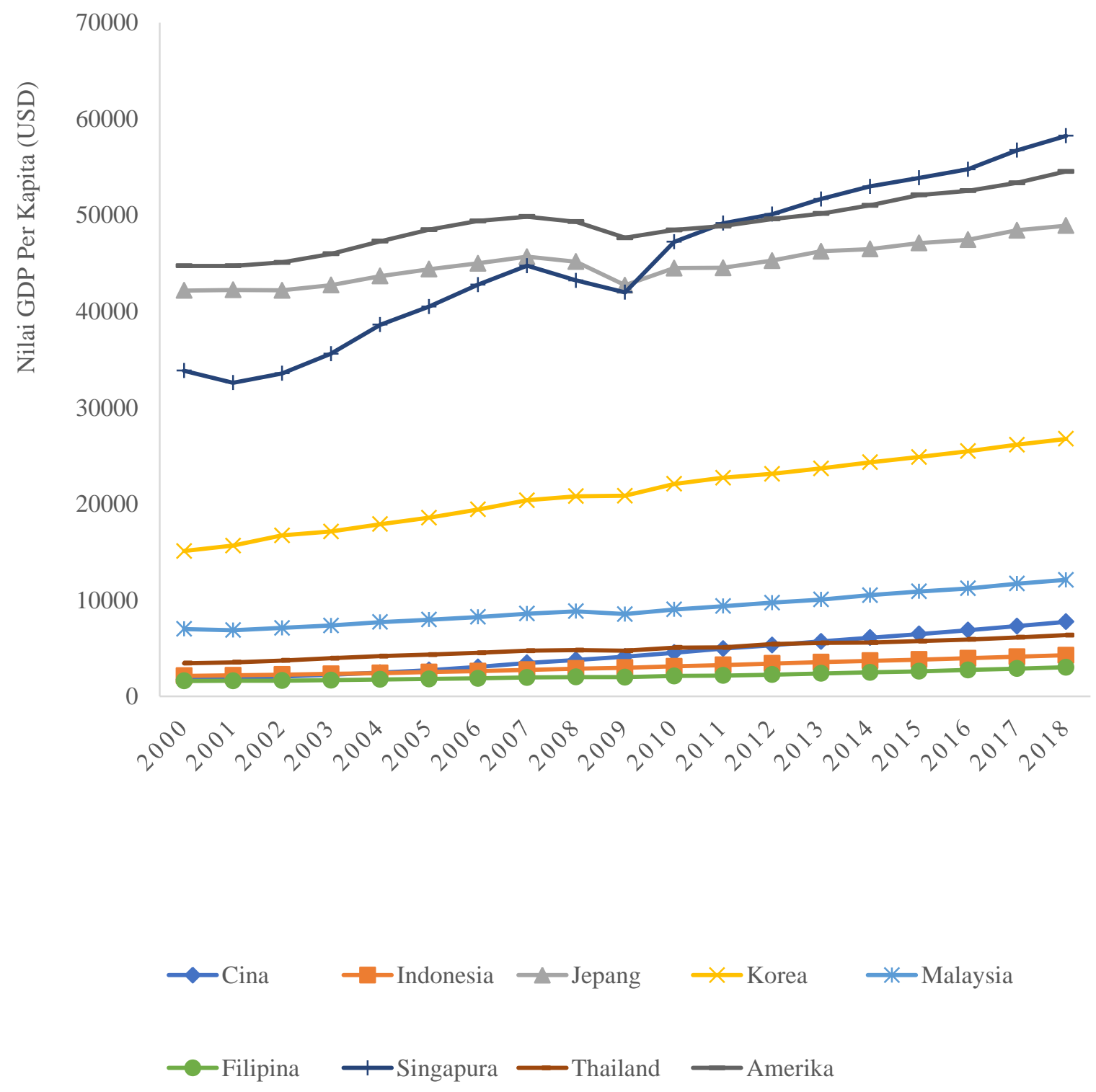

Sumber : World Bank 2019

Gambar 5. Nilai GDP per kapita negara ACFTA+3 tahun 200-2018 (USD)

Gambar 5 menunjukan nilai GDP per Kapita negara ACFTA+3. GDP per kapita juga disebut dapat disebut juga rata-rata pendapatan penduduk suatu negara, jadi apabila GDP per kapita meningkat maka pendapatan masyarakat meningkat pula. Apabila GDP per kapita suatu negara mengalami peningkatan maka negara tersebut memiliki kemampuan daya beli yang lebih, sehingga GDP per kapita memengaruhi 
perubahan volume perdagangan antar negara (Mankiw 2006).

GDP per kapita Singapura menjadi GDP per kapita terbesar di kawasan ACFTA dengan ratarata sebesar 45382.7 USD. GDP per kapita Indonesia menjadi negara ketiga terbesar dengan rata-rata GDP per kapita 3073.3 USD. GDP per kapita terendah diantara negara ACFTA+3 yaitu Filipina dengan rata-rata sebesar 2142.8 USD. Sementara Cina meski dengan nilai GDP riil tertinggi, rata-rata GDP per kapitanya masih jauh di bawah Singapura yaitu sebesar 4 354.3 USD. Untuk mitra dagang utama lainnya, Amerika memiliki rata-rata nilai GDP per kapita tertinggi diantara negara ACFTA+3 yaitu sebesar 49114.5 USD dan mencapai nilai tertingginya di tahun 2018 mencapai 54541.7 USD. Negara Jepang dan Korea sebagai negara maju di ASEAN memiliki rata-rata GDP per kapita yang tinggi dimana ratarata GDP per kapitanya yaitu 44997.0 USD dan 21 146.8 USD. Berdasar data di atas dapat kita nyatakan bahwa Singapura memiliki kemampuan yang lebih tinggi dalam perdagangan internasional dibanding negara lain dalam kawasan ACFTA.

Nilai perdagangan impor Indonesia dengan negara ACFTA+3 setelah diberlakukannya kesepakatan ACFTA cenderung meningkat. Ratarata nilai impor Indonesia dengan negara-negara di dalam kawasan ASEAN (Malaysia, Singapura, Thailand, dan Filipina) mencapai 8 Miliar USD dengan rata-rata pertumbuhan nilai impor sebesar 15 persen setelah diberlakukan ACFTA.

Perdagangan impor Indonesia dalam kawasan ACFTA didominasi oleh Cina dan Singapura. Pada Tahun 2018, nilai impor Indonesia dari Cina mencapai 45 Miliar USD atau mengalami pertumbuhan 32 persen dari tahun sebelumnya, kemudian impor dari Singapura bernilai 21.4 Miliar USD, sementara negara lain dalam kawasan rata-rata nilai impornya kurang dari 15 Miliar USD. Nilai impor Indonesia dari Cina terlihat meningkat sangat signifikan akibat dari kesepakatan ACFTA dimana rata-rata nilai impor dari Cina mencapai 22.1 Miliar USD atau mengalami pertumbuhan rata-rata 21 persen. Sementara nilai impor Indonesia dari Singapura tumbuh dengan rata-rata 16 persen atau senilai 17.8 Miliar setelah ACFTA. Hal ini disebabkan karena Cina memberikan harga barang yang reltif lebih murah dibandingkan dengan negara lain, sementara Singapura sendiri merupakan pusat perdagangan barang dan keuangan untuk kawasan Asia Tenggara (WITS 2019).

Selain negara-negara dalam kawasan ACFTA, terdapat tiga negara mitra dagang utama Indonesia. Nilai impor dari negara-negara non anggota ACFTA (Amerika, Jepang, dan Korea) mengalami pertumbuhan rata-rata sebesar 14 persen setelah diberlakukan ACFTA. Persentase nilai total perdagangan Jepang yang mencapai 10 persen juga ditunjukan juga dengan besarnya aliran impor Indonesia dari Jepang. Pada tahun 2018 nilai impor Indonesia dari Jepang mencapai 17.9 Miliar USD. Kemudian nilai impor negara mitra dagang utama lainnya yaitu Amerika dan Korea memiliki nilai impor masing-masing pada tahun 2018 sebesar 10.2 Miliar USD dan 9.1 Miliar USD.

Secara umum perdagangan impor dari negara kawasan ACFTA+3 sebagai negara mitra dagang utama Indonesia memiliki tren yang cenderung meningkat dari tahun 2000-2018. Adapun fluktuasi pada nilai impor Indonesia dari negara-negara ACFTA+3 mengalami penurunan pada tahun 2009 yang disebabkan adanya krisis ekonomi dan keuangan global yang memengaruhi nilai tukar rupiah. Kemudian kembali terjadi penurunan di beberapa tahun terakhir yang juga disebabkan karena melemahnya nilai tukar rupiah. Sementara impor dari negara Cina dapat dikatakan lebih stabil karena barang-barang yang berasal dari Cina memiliki harga yang relatif lebih murah dengan spesifikasi produk tertentu.

Persentase total nilai impor Indonesia pada tahun 2018 menunjukkan jumlah nilai impor Indonesia dari ASEAN dan Cina mendominasi dengan jumlah persentase masing-masing sebesar 24 persen. Jepang, Korea dan Amerika sebagai negara pengekspor utama produk impor ke Indonesia masing-masing memiliki persentase 10 persen, 5 persen, dan 5 persen terhadap total nilai impor Indonesia. Hal ini menunjukan bahwa perdagangan impor Indonesia di kawasan ACFTA 
cukup besar. Kemudahan perdagangan di dalam kawasan ACFTA meningkatkan arus perdagangan antar negara dalam kawasan.

Sementara itu dari daftar 10 nama produk impor utama Indonesia dengan nilai total impor Indonesia pada tahun 2016 hingga 2018, produk terbanyak yang diimpor oleh Indonesia adalah minyak ringan dan preparatnya dengan kode HS 271012, dimana nilai impornya semakin tinggi dalam 3 tahun terakhir. Pada tahun 2018 nilai impor minyak ringan dan preparatnya mencapai 11070.5 juta USD. Impor minyak ringan dan preparatnya ini 75 persen berasal dari ASEAN atau setara dengan nilai 8351.9 juta USD. Negara pengekspor utama dari ASEAN yaitu Singapura dan Malaysia dengan masing-masing bernilai 7572.4 juta USD dan 1 054.6 juta USD (Trademap 2019). Kemudian untuk sepuluh produk impor utama lainnya yaitu Minyak petroleum dan minyak yang diperoleh dari mineral mengandung bitumen; Gandum, Emas; Bungkil; Gula Tebu; Propana dan Butana.

Produk utama yang diimpor dari Cina sebagai mitra dagang kesepakatan ACFTA yaitu perangkat telepon, termasuk telepon untuk jaringan seluler atau untuk mengirimkan atau menerima suara, gambar, atau data lainnya termasuk aparatus untuk komunikasi dalam jaringan kabel atau tanpa kabel yang nilainya mencapai 2886.0 juta USD atau setara dengan 68.7 persen dari total impor produk yang sama dari pasar dunia (Trademap 2019). Produk utama lainnya juga termasuk komponen komunikasi elektronik seperti mesin untuk pengolah data digital, serta penyiaran-penyiaran radio atau televisi. Selain itu impor utama dari produk pertanian yaitu bawang putih dan apel segar, serta impor utama lainnya yaitu produk yang mangandung besi dan baja untuk infrastruktur, ubin, dan mesin untuk kendaraan besar seperti truck dan crane.

Kedua produk ini diduga menjadi produk utama impor karena adanya pertumbuhan pembangunan infrastruktur dan transportasi yang menggunakan jenis minyak tersebut baik sebagai bahan bakar maupun campuran untuk aspal pada jalan, serta perkembangan jaringan komunikasi, internet dan perangkatnya sehingga permintaan akan produk tersebut menjadi besar.

Impor Indonesia dari Amerika utamanya yaitu mengimpor kacang kedelai, yang nilainya pada tahun 2018 mencapai 1.07 Miliar USD (Trademap 2019). Selain kacang kedelai Indonesia juga banyak mengimpor hasil pertanian lain seperti kapas dan gandum dari Amerika. Sementara untuk Jepang dan Korea rata-rata Indonesia mengimpor mesin atau bagian daripada mesin, yang diperuntukan untuk truck, kendaraan bermotor, alat berat dan lain lain.

Faktor-faktor yang Memengaruhi Impor Indonesia dengan Negara ACFTA+3

Model panel data penelitian ini menggunakan Fixed Effect Model (FEM) dengan pembobotan General Least Square (GLS) Cross Section SUR. Pemilihan model berdasarkan hasil Uji Chow yang menunjukan probabilitas 0.00 (lampiran 2), sehingga jika $p$-value lebih kecil dari taraf nyata yang digunakan maka cukup bukti untuk model yang digunakan adalah FEM. Sementara pembobotan SUR cross-section weighted untuk mengatasi heteroskedastisitas dan autokorelsi antar unit cross-section.

Hasil estimasi memenuhi uji kelayakan model dengan nilai probability (F-Statistic) pada model yang digunakan adalah 0.00 sehingga dapat disimpulkan bahwa minimal ada satu variabel bebas yang memengaruhi variabel tidak bebas. Sementara uji kecocokan model (goodness of fit) ditunjukkan pada nilai koefisien determinasi $\left(\mathrm{R}^{2}\right)$. Model menunjukkan nilai $\mathrm{R}^{2}$ sebesar 0.99 yang berarti variasi variabel bebas mampu menjelaskan 99 persen variasi variabel tidak bebas, sisanya dijelaskan oleh variabel lainnya di luar model.

Uji normalitas dilakukan dengan melihat nilai probabilitas pada uji normalitas lebih besar dari taraf nyata 5 persen. Hasil uji normalitas model ini didapati nilai probabilitasnya sebesar 0.14 atau lebih besar dari taraf nyata 5 persen. Kondisi ini menandakan bahwa cukup bukti untuk menerima atau dengan kata lain error yang terdapat pada model telah terdistribusi dengan normal. 
Tabel 1 Koefisien penduga nilai impor Indonesia

\begin{tabular}{lcc}
\hline \multicolumn{1}{c}{ Variabel } & Koefisien & Probabilitas \\
\hline $\mathrm{GDPC}_{\mathrm{it}}$ & $1.04^{* *}$ & 0.00 \\
$\mathrm{GDPC}_{\mathrm{jt}}$ & $1.44^{* *}$ & 0.00 \\
$\mathrm{RER}_{\mathrm{ijt}}$ & $-0.60^{*}$ & 0.02 \\
DIST $_{\mathrm{ijt}}$ & $-0.92^{* *}$ & 0.00 \\
DFTA $_{\mathrm{t}}$ & $0.24^{* *}$ & 0.00 \\
DIM $_{\mathrm{cr}}$ & $0.07^{* *}$ & 0.00 \\
DIM $_{\mathrm{dv}}$ & $-0.12^{* *}$ & 0.00 \\
$\mathrm{C}$ & $-1.79^{*}$ & 0.04 \\
\hline $\mathrm{R}$-squared & 0.995286 & \\
Adjusted R-squared & 0.994804 & \\
\hline
\end{tabular}

*signifikan pada taraf nyata 5\%

**signifikan pada taraf nyata $1 \%$

Sumber : Hasil olahan

Hasil estimasi yang ditunjukkan pada Tabel 1 menunjukan terdapat 5 variabel bebas yang berpengaruh signifikan terhadap arus impor dengan taraf nyata lima persen, yaitu GDP per kapita Indonesia, GDP per kapita mitra dagang, nilai tukar dua negara, jarak ekonomi, dan dummy kebijakan. Hasil olahan penelitian ini sejalan dengan temuan yang dilakukan oleh Zidi dan Dhifallah (2013) dan Ritaningsih (2014).

Peningkatan pendapatan per kapita Indonesia berpengaruh nyata terhadap peningkatan nilai impor Indonesia dari negara-negara ACFTA +3 . Peningkatan pendapatan per kapita Indonesia sebesar satu persen akan meningkatkan nilai impor Indonesia sebesar 1.04 persen, ceteris paribus. Pendapatan per kapita Indonesia menunjukan kemampuan Indonesia dalam perdagangan, sehingga semakin besar kemampuan negara tersebut akan meningkatkan permintaan terhadap impor. Menurut Fitzsimons et al (1999) menyatakan peningkatan GDP per kapita negara pengekspor akan meningkatkan kemampuan produksi negara tersebut, sedangkan meningkatnya GDP per kapita negara pengimpor akan meningkatkan konsumsi negara tersebut sehingga permintaan akan impor suatu komoditi akan mengalami peningkatan. GDP per kapita suatu negara lebih merepresentasikan kemampuan daya beli masyarakat. Negara maju memiliki tingkat GDP per kapita yang jauh lebih tinggi dibandingkan GDP per kapita negara berkembang.

Pendapatan per kapita negara ACFTA+3 menunjukkan pengaruh yang positif dan signifikan sebesar 1.44. Hal ini berarti peningkatan pendapatan per kapita negara ACFTA+3 sebesar satu persen akan meningkatkan nilai impor Indonesia sebesar 1.44 persen, ceteris paribus. Hasil penelitian ini sejalan dengan temuan yang dilakukan oleh Robert (2010). Tanda positif pada koefisien sesuai dengan hipotesis penelitian. Pendapatan per kapita mengindikasikan adanya peningkatan pendapatan dan kemampuan ekonomi dikarenakan terjadi peningkatan produksi di negara mitra dagang sehingga dapat meningkatkan penawaran barang impor.

Kemudian, nilai tukar rupiah terhadap mata uang negara pengekspor memberikan pengaruh nyata terhadap nilai impor Indonesia sebesar -0.60 . Koefisien yang bernilai negatif berarti bahwa setiap peningkatan nilai tukar riil rupiah sebesar 
satu persen akan menurunkan nilai impor sebesar 0.60 persen, ceteris paribus. Sesuai dengan penelitian Ritaningsih (2014), hubungan negatif nilai tukar rill dengan nilai impor tersebut mengimplikasikan bahwa depresiasi pada nilai tukar riil dapat menaikkan harga impor di dalam negeri sehingga menurunkan permintaan barang dan nilai impor Indonesia terhadap negara mitra dagang.

Jarak ekonomi digunakan sebagai pendekatan biaya transportasi suatu negara dalam melakukan kegiatan ekonomi dengan negara lain. Jarak merupakan sebuah proxy untuk menghitung biaya transportasi. Oleh karena itu, semakin besar jarak antara dua negara maka semakin tinggi biaya transportasi yang akan dihasilkannya, kemudian akan meningkatkan harga barang yang diperdagangkan sehingga mengurangi daya saing negara mitra dagang (Zidi dan Dhifallah, 2013). Hasil estimasi menunjukkan bahwa variabel jarak ekonomi berpengaruh negatif signifikan terhadap nilai impor dengan taraf nyata lima persen, dengan besaran nilainya yaitu -0.92 . Koefisien tersebut bernilai negatif dapat diartikan bahwa setiap peningkatan jarak ekonomi antar kedua negara sebesar satu persen akan menurunkan nilai impor sebesar 0.92 persen, ceteris paribus. Menurut Beers (2002) dan Paas (2000) hubungan jarak ekonomi dengan arus perdagangan disebabkan oleh tingginya biaya sehingga harga barang-barang impor akan mengalami peningkatan.

Sejalan dengan penelitian sebelumnya oleh Ritaningsih (2014) dan Darsono (2015), variabel Dummy FTA menunjukan adanya perbedaan terhadap nilai impor negara Indonesia dengan negara ACFTA+3 karena pemberlakuan ACFTA. Variabel dummy kebijakan FTA digunakan untuk menangkap perbedaan tahun saat sebelum dan sesudah ACFTA diberlakukan untuk tiap tahunnya. Koefisien tersebut menggambarkan bahwa pemberlakuan ACFTA memiliki rata-rata perbedaan nilai impor Indonesia sebesar 0.24 satuan terjadi setelah ACFTA diberlakukan.

Variabel dummy trade creation dan dummy trade diversion digunakan untuk menangkap dampak dari ACFTA pada arus impor Indonesia. berdasarkan hasil estimasi, nilai koefisien pada dummy trade creation bernilai 0.07 , sedangkan koefisien dummy trade diversion bernilai -0.12 . Simpulan dari hasil estimasi dua koefisien dummy ini yaitu bahwa terjadi efek trade diversion pada arus impor perdagangan Indonesia dengan negara ACFTA +3, karena koefisien trade creation menunjukan nilai positif sementara koefisien trade diversion bernilai negatif. Hal ini mengindikasikan bahwa impor Indonesia dengan negara nonanggota sebesar 12.74 persen [(exp(-1,21)-1)*100] lebih sedikit dari tingkat perdagangan yang saat ini dilakukan dengan negara non-anggota.

Pemberlakuan kesepakatan FTA akan memiliki dampak berbeda pada Indonesia. Penelitian Darsono (2015) menyatakan bahwa adanya kesepakatan AJCEP (ASEAN-Japan Comprehensive Economic Partnership) berdampak terjadinya trade creation bagi perdagangan Indonesia. Hal ini dapat juga tergambar dari neraca perdagangan Indonesia dengan Jepang yang bernilai positif atau surplus.

Sementara pemberlakuan ACFTA setelah dianalisis pada penelitian ini menyebabkan arus perdagangan impor Indonesia mengalami trade diversion. Trade diversion yang terjadi karena penurunan tarif dari negara anggota ASEAN-China dan adanya harga penawaran yang lebih rendah. Trade diversion pun terjadi pada Indonesia setelah diberlakukannya kesepakatan AKFTA (ASEANKoren Free Trade Area). Menurut penelitian Ritaningsih (2014) terjadinya trade diversion pada perdagangan impor Indonesia karena adanya penurunan tarif secara bertahap pada beberapa produk yang disepakati dalam AKFTA yang juga diimpor dari dunia dengan harga penawaran yang lebih rendah sehingga Indonesia lebih memilih untuk mengimpor produk-produk dari kawasan ASEAN-Korea dibandingkan dari negara pengekspor lainnya. Secara keseluruhan, Indonesia mengalami kerugian akibat terjadinya trade diversion yang dapat berdampak pada pengurangan kesejahteraan nasional. 


\section{KESIMPULAN}

Gambaran karakter ekonomi negara-negara ACFTA+3 secara umum pada tahun 2000-2018 dibagi menjadi 3 kelompok negara berdasarkan pertumbuhan ekonminya. Negara Cina dan Amerika dapat dikatakan sebagai negara-negara kelompok pertama, dimana memiliki pertumbuhan ekonomi yang pesat. Negara Singapura, Jepang dan Korea dapat dikatakan masuk dalam kelompok kedua dimana pertumbuhan ekonominya cenderung fluktuatif namun memiliki nilai yang cukup tinggi. Sementara negara-negara lainnya seperti Indonesia, Thailand, Malaysia dan Filipina menjadi negara kelompok ketiga sebagai negara berkembang.

Gambaran umum nilai perdagangan impor Indonesia dengan negara ACFTA+3 setelah diberlakukannya kesepakatan ACFTA cenderung meningkat. Sementara perdagangan impor Indonesia terhadap non anggota ACFTA masih didominasi oleh negara-negara dalam kelompok pertama dan kedua, yaitu Amerika, Singapura, dan Jepang.

Hasil penelitian menunjukan bahwa sebagai dampak dari integrasi ekonomi dengan pemberlakuan ACFTA, nilai impor Indonesia dengan negara ACFTA+3 meningkat. Nilai perdagangan impor Indonesia secara signifikan dipengaruhi positif oleh GDP per kapita Indonesia, GDP per kapita mitra dagang (ACFTA+3), jarak ekonomi, serta kebijakan ACFTA. Sementara nilai tukar antar negara berpengaruh negatif terhadap nilai impor Indonesia.

Kebijakan ACFTA menyebabkan trade diversion pada arus impor Indonesia dari negara non-anggota (Amerika, Jepang, dan Korea) ke negara-negara anggota dalam ACFTA. ACFTA menyebabkan nilai impor Indonesia dengan negara non-anggota sebesar 12.74 persen lebih rendah dari tingkat perdagangan yang saat ini. Secara keseluruhan Indonesia akan mengalami kerugian karena adanya trade diversion tersebut, dikarenakan adanya pengurangan hambatan perdagangan mendorong peningkatan arus impor dari biaya yang lebih rendah ke biaya yang lebih tinggi di kawasan ACFTA.

Merujuk pada hasil estimasi ada beberapa hal yang disarankan untuk dilakukan. Nilai tukar riil merupakan salah satu variabel yang memengaruhi nilai impor Indonesia diharapkan dapat menjadi indikator kebijakan pemerintah. Kestabilan nilai tukar riil menjadi penting untuk mengontrol nilai perdagangan. Seperti yang dilihat pada gambaran umum produk yang diimpor Indonesia masih didominasi oleh impor migas. Maka sebaiknya peningkatan impor yang dilakukan dalam kawasan ACFTA harus lebih selektif diarahkan pada barang-barang impor seperti bahan baku yang dapat memiliki nilai tambah atau dapat berorientasi ekspor. Hal ini perlu dilakukan agar dapat meningkatkan nilai tambah barang dan Indonesia dapat mengambil opsi perdagangan dalam global value chain.

Trade diversion Indonesia di negara-negara ACFTA+3 akibat ACFTA dapat mengurangi kesejahteraan nasional maka pemerintah perlu bernegosiasi dengan penurunan tarif negara mitra dagang non-anggota kawasan untuk memberikan harga penawaran yang lebih rendah atau mendekati harga penawaran dari negara anggota kawasan sehingga kesejahteraan nasional akan meningkat. Pemerintah perlu melakukan negosiasi harga dengan negara mitra dagang non anggota ACFTA untuk mencegah trade diversion. Kemudian untuk menahan arus impor akibat penurunan tarif perlunya kebijakan lain di luar tarif seperti adanya standarisasi produk yang masuk. Di sisi lain, Indonesia juga perlu belajar menyesuaikan produknya dengan standar pasar di negara-negara ACFTA.

Pemanfaatan preferential treatment dalam kawasan dijadikan pendorong Indonesia untuk meningkatkan produksi barang untuk substitusi impor dan meningkatkan daya saing produk dalam negeri sehingga dapat memenuhi kebutuhan dalam negeri dan meningkatkan kegiatan ekspor.

Indonesia juga diharapkan dapat memanfaatkan kemudahan perdagangan dalam kawasan dengan membuka akses pasar untuk produk-produk baru agar tercipta trade creation dalam kawasan 
ACFTA yang kemudian akan memberikan keuntungan yang lebih besar dalam peningkatan kesejahteraan Indonesia. Oleh sebab itu, diperlukan pengoptimalan kesepakatan melalui kesepakatan bilateral.

Dari model yang digunakan dalam penelitian ini, dapat dikembangkan model lebih lanjut guna memperoleh hasil yang lebih baik, oleh karena itu saran peneliti lebih lanjut adalah, penambahan jenis variabel dari proksi trade creation atau trade diversion, melakukan spesifikasi produk sisi komoditi, serta penambahan cakupan penelitian dengan memasukkan kawasan lain sebagai pembanding dimana Indonesia menjadi negara anggota. Menggunakan metode lain, seperti Global Trade Analysis Project (GTAP) atau Computable General Equilibrium (CGE), dalam melihat dampak perekonomian secara menyeluruh.

\section{DAFTAR PUSTAKA}

Astiyah S, Hutabarat AR, Sianipar DV. 2005. Dampak Liberalisasi Perdagangan terhadap Perilaku Pembentukan Harga Produk Industri Melalui Structure Conduct Performance Model. Buletin Ekonomi Moneter dan Perbankan 7(4): 523-554.

Darsono, TA. 2015. Analisis Dampak ASEANJapan Comprehensive Economic Partnership (AJCEP) terhadap arus Perdagangan dan Konvergensi Pertumbuhan Ekonomi [Tesis]. Bogor (ID): Institut Pertanian Bogor

Elliot RJR, Ikemoto K. 2004. AFTA and the Asian Crisis: Help or Hindrance to ASEAN IntraRegional Trade?. Asian Economic Journal 2004, 18(1): 1-23.

Fitzsimons, Emla, Vincent H, Peter N. Explaining the Volume of North-South Trade in Ireland: A Gravity Model Approach.
University College Dublin: The Economic and Social Review, Vol 30 No. 4.

[Kementerian Perdagangan], 2015. Analisis Potensi dan Manfaat Rantai Nilai Kawasan Regional Comprehensive Economic Partnership Bagi Indonesia.Jakarta

Ritaningsih, T. 2014. Trade Creation dan Trade Diversion antara Indonesia dan negaranegara ASEAN-Korea [Tesis]. Bogor (ID): Institut Pertanian Bogor

Roberts B. 2004. A Gravity Study of the Proposed China-ASEAN Free Trade Area. The International Trade Journal, 18 (4): 335353.

Salvatore D. 1996. International Economics, Fifth Edition. New Jersey: Prentice-Hall, Inc.

Sharma SC, Chua SY. 2000. ASEAN economic integration and intra-regional trade. Applied Economics Letter, 7(3) : 165-69.

Thornton J, Goglio A. 2002. Regional Bias and Intra-Regional Trade in Southeast Asia. Applied Economics Letters, 9(4) : 205-208.

[Trademap] Berbagai terbitan [Internet]. [diunduh Mei 2019]. Tersedia pada: https://www.trademap.org/

Yang S, Martinez-Zarzoso I. 2013. A Panel Data Analysis of Trade Creation and Trade Diversion Effects : The case of ASEANChina Free Trade Area (FTA). Discussion Paper for Economic Research. Germany : Faculty of Economic Sciences, University of Goettingen.

Zidi A, Dhifallah SM. 2013. Trade Creation and Trade Diversion between Tunisia and EU: Analysis by Gravity Model. International Journal Economics and Finance, 5(5): 131-147 